Jurnal Manajemen dan Kewirausahaan, Volume 9, Nomor 2, Mei 2018

ISSN 2086-5031

E-ISSN 2615-3300

DOI 10.31317

\title{
Pengaruh Pengetahuan Kewirausahaan dan Praktek Kewirausahaan dalam Menumbuhkembangkan Perilaku Kewirausahaan Mahasiswa
}

(Studi Pada Mahasiswa Perguruan Tinggi Swasta di Kota Padang)

\author{
Oleh: \\ Ramadhania \\ Fakultas Ekonomi Universitas Tamansiswa Padang \\ ramadhania010589@gmail.com
}

\begin{abstract}
Abstrak
Penelitian ini bertujuan untuk mengetahui dan menganalisis pengaruh pengetahuan kewirausahaan dan praktek kewirausahaan dalam menumbuhkembangkan perilaku kewirausahaan mahasiswa di Kota Padang baik secara parsial maupun simultan. Penelitian ini menggunakan metode kuantitatif deskriptif. Populasi penelitian adalah seluruh mahasiswa perguruan tinggi swasta di Kota Padang dengan jumlah sampel 100 orang responden menggunakan rumus Slovin. Teknik pengambilan sampel menggunakan simple random sampling. Pengujian yang dilakukan antara lain uji regresi berganda, uji t, uji F, dan koefisien determinasi $\left(\mathrm{R}^{2}\right)$. Hasil penelitian menunjukkan bahwa; 1) pengetahuan kewirausahaan berpengaruh signifikan dalam menumbuhkembangkan perilaku kewirausahaan dengan nilai $t_{\text {hitung }}$ sebesar 2,248 > $t_{\text {tabel }}$ sebesar 1,984 dengan nilai signifikan $0,000<0,05$; 2) praktek kewirausahaan berpengaruh signifikan dalam menumbuhkembangkan perilaku kewirausahaan dengan nilai $t_{\text {hitung }}$ sebesar 3,377 $>t_{\text {tabel }}$ sebesar 1,984 dengan nilai signifikan $0,000<0,05$. Berdasarkan hasil uji $\mathrm{F}$, secara simultan pengetahuan kewirausahaan dan praktek kewirausahaan berpengaruh signifikan dalam menumbuhkembangkan perilaku kewirausahaan mahasiswa. Nilai koefisien determinasi sebesar 0,339 yang berarti besarnya pengaruh pengetahuan kewirausahaan dan praktek kewirausahaan dalam menumbuhkembangkan perilaku kewirausahaan mahasiswa di Kota Padang sebesar $33,9 \%$, sedangkan sisanya sebesar $66,1 \%$ dipengaruhi oleh variabel lain yang tidak diteliti dalam penelitian ini.
\end{abstract}

Kata kunci: Perilaku Kewirausahaan, Pengetahuan Kewirausahaan, Praktek Kewirausahaan

\section{PENDAHULUAN}

\section{Latar Belakang Masalah}

Dalam rangka memasuki era revolusi

industry 4.0, perguruan tinggi terus

berupaya untuk mengembangkan potensi

sumberdaya manusia terutama mahasiswa yang perlu untuk menumbuhkembangkan cerminan perilaku kewirausahaan. Apalagi saat sekarang sangat dibutuhkan lulusan perguruan tinggi yang memiliki skill dalam menciptakan usaha sendiri yang dikenal dengan menjadi entrepreneur. untuk 
Jurnal Manajemen dan Kewirausahaan, Volume 9, Nomor 2, Mei 2018

ISSN 2086-5031

E-ISSN 2615-3300

DOI 10.31317

menjadi seorang entrepreneur tentunya sangat diperlukan pengetahuan tentang kewirausahaan dan diimplementasikan dalam bentuk praktek kewirausahaan dan dicerminkan melalui perilaku entrepreneur itu sendiri.

Berdasarkan data Badan Pusat Statistik (BPS) tahun 2016, menjelaskan rasio wirausaha di Indonesia sebesar 3,10 persen dari jumlah penduduk sebanyak 225 juta orang. pertumbuhan wirausaha baru mencapai angka 1,65 persen dari jumlah penduduk, jauh tertinggal dibandingkan dengan negara tetangga seperti Malaysia, Thailand, dan Singapura yang sudah mencapai di atas 4 persen. sedangkan, jumlah wirausaha Indonesia hanya 2 persen dari total penduduknya sebanyak 230 jiwa. Artinya, terdapat 2 orang dari setiap 100 orang penduduk yang membuka lapangan pekerjaan dan 1 orang wirausaha menghidupi 49 orang yang bukan wirausaha. hal ini berarti Indonesia masih kekurangan jumlah wirausaha yang perlu dimaksimalkan untuk menghadapi tantangan revolusi industry 4.0.

Dilihat dari fenomena yang diamati dari hasil observasi yang dilakukan, didapatkan informasi bahwa sebagian mahasiswa masih belum memiliki dan menerapkan perilaku kewirausahaan. Perilaku kewirausahaan merupakan kemampuan kreatif dan inovatif yang dijadikan kiat, dasar, sumber daya, proses dan perjuangan untuk menciptakan nilai tambah barang dan jasa yang dilakukan dengan keberanian untuk menghadapi risiko". Kebanyakan dari mahasiswa cenderung untuk mengembangkan perilaku kewirausahaan ketika sudah lulus dari perguruan tinggi dan malahan ada yang tidak membina dirinya dalam menciptakan perilaku kewirausahaan. Mahasiswa cenderung untuk mencari kerja karena jika mengembangkan usaha akan menemui resiko dan tidak semuanya mampu untuk menanggungnya.

Selain itu, lebih banyak yang gemar membeli suatu produk daripada menbuatnya sendiri karena berpikiran lebih sederhana dan mudah untuk membeli daripada membuat. Pola pikir seperti itulah yang akan mempengaruhi mahasiswa untuk mampu membentuk perilaku kewirausahaan. Alasannya, untuk menjadi seorang wirausaha harus selalu berkomitmen dalam melakukan tugasnya hingga memperoleh hasil yang diharapkan, Oleh sebab itu, 
Jurnal Manajemen dan Kewirausahaan, Volume 9, Nomor 2, Mei 2018

ISSN 2086-5031

E-ISSN 2615-3300

DOI 10.31317

ketekunan, ulet, dan pantang menyerah menjadi pondasinya untuk mencapai hal tersebut. Pengetahuan kewirausahaan yang masih minim diterima oleh mahasiswa juga mempengaruhi perilaku kewirausahaannya. Rendahnya pengetahuan kewirausahaan berakibat pada kemampuan mahasiswa untuk mengembangkan kegiatan berwirausahanya selain keterbatasan modal dan sumberdaya manusia.

Dalam rangka menumbuhkan perilaku dalam berwirausaha, pihak perguruan tinggi dapat memberikan pembekalan pengetahuan tentang kewirausahaan melalui proses pembelajaran atau perkuliahan. Pengetahuan kewirausahaan dapat membentuk pola pikir, dan perilaku pada mahasiswa menjadi seorang wirausaha. Hal ini dapat mengarahkan mahasiswa untuk memilih berwirausaha sebagai salah satu pilihan karir kedepannya. Selain itu, pengetahuan kewirausahaan merupakan salah satu faktor pemicu seseorang dalam berperilaku sebagai wirausaha yang berasal dari domain individu. Adanya sumber-sumber yang dapat dimanfaatkan, pelatihan, seminar bisnis dapat mendorong seorang berwirausaha.
Suryana (2013: 80) menyatakan bahwa "seorang wirausaha tidak akan berhasil apabila tidak memiliki pengetahuan, kemampuan, dan kemauan”. Ada kemauan tapi tidak memiliki kemampuan dan pengetahuan tidak akan membuat seseorang menjadi wirausaha sukses, sebaliknya memiliki pengetahuan dan kemampuan tetapi tidak disertai kemauan tidak akan membuat wirausaha mencapai kesuksesan. Jadi, tanpa pengetahuan, kemampuan dan kemauan maka seseorang yang menjadi wirausaha tidak akan berhasil dalam menjalankan usahanya. Ini berarti pengetahuan, kemampuan dan kemampuan saling berhubungan satu sama lain. Dengan terus mengembangkan pengetahuan kewirausahaan, tujuan untuk menjadi wirausaha dapat dilaksanakan dengan baik didukung oleh berbagai pihak pendukung terbangunnya konsep kewirausahaan.

Praktek kewirausahaan merupakan kegiatan dalam mengembangkan dan mengaplikasikan langsung ide-ide kreatif mahasiswa yang mengarah kepada menciptakan suatu produk yang bernilai jual dan memasarkannya kepada konsumen. Hal ini dilakukan agar mahasiswa mampu bersosialisasi dengan masyarakat sehingga 
Jurnal Manajemen dan Kewirausahaan, Volume 9, Nomor 2, Mei 2018

ISSN 2086-5031

E-ISSN 2615-3300

DOI 10.31317

memudahkan dalam proses komunikasi dan interaksi demi kelancaran produk yang akan dijual. Selain itu, diharapkan mahasiswa timbul keinginannya untuk terus menggeluti kegiatan usaha ini dan mengembangkannya lebih luas dan bisa mendapatkan penghasilan sendiri serta tidak tergantung pada lapangan kerja yang ada. tanpa adanya praktek kewirausahaan, pengetahuan kewirausahaan tidak akan berjalan dengan lancar. Kegiatan ini masih minim dijalankan oleh mahasiswa di perguruan tinggi swasta di Kota Padang.

\section{Rumusan Masalah}

Berdasarkan latar belakang masalah penelitian yang sudah dijelaskan sebelumnya, maka rumusan masalah dalam penelitian ini adalah sebagai berikut:

a. Bagaimana pengaruh pengetahuan kewirausahaan dalam menumbuh kembangkan perilaku kewirausahaan mahasiswa di KotaPadang?

b. Bagaimana pengaruh praktek kewirausahaan dalam menumbuh kembangkan perilaku kewirausahaan mahasiswa di KotaPadang?

c. Bagaimana pengaruh pengetahuan kewirausahaan dan praktek kewirausahaan dalam menumbuh kembangkan perilaku kewirausahaan mahasiswa di KotaPadang?

\section{Tujuan Penelitian}

Tujuan dari penelitian ini adalah sebagai berikut:

a. Mengetahui pengaruh pengetahuan kewirausahaan dalam menumbuh kembangkan perilaku kewirausahaan mahasiswa di KotaPadang

b. Mengetahui pengaruh praktek kewirausahaan dalam menumbuh kembangkan perilaku kewirausahaan mahasiswa di KotaPadang

c. Mengetahui pengaruh pengetahuan kewirausahaan dan praktek kewirausahaan dalam menumbuh kembangkan perilaku kewirausahaan mahasiswa di KotaPadang.

\section{TINJAUAN PUSTAKA}

\section{Pengetahuan Kewirausahaan}

Menurut Kuntowicaksono dalam Apriliani (2015: 12) mengemukakan bahwa pengetahuan melibatkan proses kognitif yang kompleks, persepsi, pembelajaran, komunikasi, asosiasi, dan penalaran. Pengetahuan diperoleh melalui pengalaman, 
Jurnal Manajemen dan Kewirausahaan, Volume 9, Nomor 2, Mei 2018

ISSN 2086-5031

E-ISSN 2615-3300

DOI 10.31317

input informasi melalui panca indera, ingatan, dan menjadi proses terus menerus berjalan sepanjang hayat. Plato menyatakan bahwa pengetahuan adalah keyakinan yang dibenarkan.

Pengetahuan kewirausahaan dapat membentuk pola pikir, sikap, dan perilaku pada siswa menjadi seorang wirausahawan (entrepreneur) sejati sehingga mengarahkan mereka untuk memilih berwirausaha sebagai pilihan karir (Retno dan Trisnadi, 2012: 113). Pengetahuan kewirausahaan didefinisikan oleh Kuntowicaksono (2012: 47) sebagai "Pemahaman seseorang terhadap wirausaha dengan berbagai karakter positif, kreatif, dan inovatif dalam mengembangkan peluang-peluang usaha menjadi kesempatan usaha yang menguntukan dirinya dan masyarakat atau konsumennya".

Pengetahuan kewirausahaan menurut Nurbaya dan Moerdiyanto (2012: 10), menyatakan bahwa "pengetahuan kewirausahaan adalah ilmu, seni maupun prilaku, sifat, ciri, dan watak seseorang yang mewujudkan gagasan inovatif ke dalam dunia nyata secara kreatif'.

Dengan demikian, pengetahuan kewirausahaan adalah pengetahuan yang didapat dari proses pembelajaran kewirausahaan yang diperoleh mahasiswa mengenai bagaimana memanfaatkan peluang usaha yang menguntungkan, bagaimana merintis usaha baru, menghasilkan tambah baru dan menghasilkan produk dan jasa baru sebagai modal untuk berwirausaha.

\section{Indikator Pengetahuan Kewirausahaan}

Menurut Suryana (2013: 81), indikator pengetahuan kewirausahaan yang perlu dimiliki antara lain:

1. Pengetahuan tentang usaha yang dirintis.

2. Pengetahuan tentang peran dan tanggung jawab.

3. Pengetahuan tentang kepribadian dan kemampuan diri.

4. Pengetahuan tentang manajemen dan organisasi bisnis.

\section{Praktek Kewirausahaan}

Menurut M. Zainuddin (2005:2) menyatakan bahwa praktik adalah strategi pembelajaran atau bentuk pengajaran yang digunakan untuk membelajarkan secara bersama-sama kemampuan psikomotorik (keterampilan), kognitif (pengetahuan) dan afektif (sikap). 
Jurnal Manajemen dan Kewirausahaan, Volume 9, Nomor 2, Mei 2018

ISSN 2086-5031

E-ISSN 2615-3300

DOI 10.31317

Menurut Noor Fuad dan Gofur Ahmad (2009:153), praktik adalah praktikpraktik yang dilakukan di luar lingkungan sekolah. Sedangkan menurut Kamus Besar Bahasa Indonesia (2005:885), praktik adalah melaksanakan sesuatu secara nyata seperti apa yang disebutkan oleh teori. Berdasarkan uraian di atas dapat disimpulkan bahwa praktik adalah strategi kegiatan pembelajaran secara nyata yang menggunakan kemampuan pengetahuan, sikap dan ketrampilan secara bersama-sama di luar lingkungan tempat belajar.

Dari kajian teori tentang praktik dan kewirausahaan, dapat disimpulkan bahwa praktik kewirausahaan adalah kegiatan pembelajaran secara nyata dengan menggunakan kemampuan pengetahuan, sikap, dan keterampilan guna membentuk karakter yang dimiliki seorang wirausaha dalam menjalankan peluang usaha dengan berani mengambil resiko, berkemampuan manajemen, melakukan kreativitas dan inovasi.

\section{Perilaku Kewirausahaan}

Keberhasilan atau kegagalan berwirausaha sangat tergantung pada pribadi wirausaha yang tercermin dari perilaku.
Suryana (2006: 18), perilaku kewirausahaan merupakan "Kemampuan kreatif dan inovatif yang dijadikan kiat, dasar, sumber daya, proses dan perjuangan untuk menciptakan nilai tambah barang dan jasa yang dilakukan dengan keberanian untuk menghadapi risiko". Wirausaha selalu berkomitmen dalam melakukan tugasnya hingga memperoleh hasil yang diharapkan. Oleh sebab itu, tekun, ulet, dan pantang menyerah menjadi dasarnya.

Menurut Wijaya (2008: 97) menyatakan bahwa "perilaku berwirausaha yaitu tindakan yang ditunjukan dengan keputusan berwirausaha”. Perilaku kewirausahaan merupakan bentuk dari aplikasi nilai-nilai kewirausahaan yang akan dilaksanakan dalam menciptakan karakteristik kewirausahaan.

David McClelland dalam Suryana (2013: 47) mengemukakan enam ciri perilaku kewirausahaan, yaitu :

1. Keterampilan mengambil keputusan dan resiko yang moderat, serta bukan atas dasar kebetulan belaka.

2. Energik, khususnya dalam berbagai bentuk kegiatan inovatif.

3. Memiliki sikap tanggung jawab individual. 
Jurnal Manajemen dan Kewirausahaan, Volume 9, Nomor 2, Mei 2018

ISSN 2086-5031

E-ISSN 2615-3300

DOI 10.31317

4. Mengetahui hasil-hasil dari berbagai keputusan yang diambilnya, dengan tolak ukur satuan uang sebagai indikator keberhasilan.

5. Mampu mengantisipasi berbagai kemungkinan di masa mendatang.

6. Memiliki kemampuan berorganisasi, meliputi kemampuan kepemimpinan dan manajerial.

Menurut M. Scarborough dan Thomas W. Zimmerr dalam Suryana (2013: 23) mengemukakan delapan karakteristik kewirausahaan adalah sebagai berikut:

1. Desire for responsibility, yaitu memiliki rasa tanggung jawab atas usaha-usaha yang dilakukanya.

2. Preference for moderate risk, yaitu lebih memilih resiko yang moderat, artinya selalu menghidarkan resiko, baik yang terlalu rendah maupun terlalu tinggi.

3. Confidence in their ability to success, yaitu memiliki kepercayaan diri untuk memperoleh kesuksesan.

4. Desire for immediate feedback, yaitu selalu menghendaki umpan balik dengan segera.

5. High level of energy, yaitu memiliki semangat dan kerja keras untuk mewujudkan keinginannya demi masa depan yang lebih baik.

6. Future orientation, yaitu berorientasi serta memiliki perspektif dan wawasan jauh ke depan.

7. Skill at organizing, yaitu memiliki keterampilan dalam mengorganisasikan sumber daya untuk menciptakan nilai tambah.

8. Value of achievement over money, yaitu lebih menghargai prestasi dari pada uang.

\section{Indikator Perilaku Kewirausahaan}

Suryana (2013: 29) mengemukakan ciri-ciri umum kewirausahaan yang dijadikan indikator perilaku kewirausahaan antara lain:

1. Motif berprestasi tinggi

2. Perspektif ke depan

3. Kreativitas tinggi

4. Perilaku inovasi tinggi

5. Komitmen terhadap pekerjaan

6. Tanggung jawab

7. Kemandirian atau ketidaktergantungan terhadap orang lain

8. Memiliki keberanian mengambil resiko

9. Selalu mencari peluang 
Jurnal Manajemen dan Kewirausahaan, Volume 9, Nomor 2, Mei 2018

ISSN 2086-5031

E-ISSN 2615-3300

DOI 10.31317

10. Jiwa kepemimpinan

11. Memiliki kemampuan manajerial

12. Memiliki kemampuan personal

\section{Kerangka Konseptual}

Kerangka berpikir dalam penelitian

ini dapat digambarkan sebagai berikut:

\section{Gambar 1. Kerangka Konseptual}

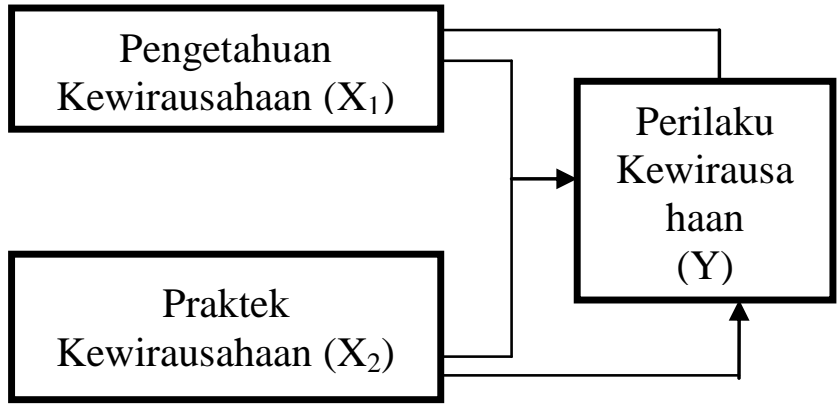

\section{Hipotesis Penelitian}

Hipotesis dalam penelitian ini adalah:

$\mathrm{H}_{1}$ : Pengetahuan kewirausahaan

berpengaruh signifikan dalam

menumbuhkembangkan perilaku

kewirausahaan mahasiswa di Kota

Padang.

$\mathrm{H}_{2}$ : Penerapan praktek kewirausahaan

berpengaruh signifikan dalam

menumbuh kembangkan perilaku

kewirausahaan mahasiswa di Kota

Padang.
$\mathrm{H}_{3}$ :Pengetahuan kewirausahaan dan penerapan praktik kewirausahaan berpengaruh signifikan dalam menumbuh kembangkan perilaku kewirausahaan mahasiswa di Kota Padang.

\section{METODE PENELITIAN}

\section{Jenis Penelitian}

Penelitian ini menggunakan metode kuantitif deskriptif. Dengan pendekatan kuantitatif yaitu penelitian yang datadatanya berupa angka-angka atau datadata yang diangkakan (Sugiyono, 2012: 22). Menurut Sekaran (2006: 158), Studi Deskriptif (descriptife Study) dilakukan untuk mengetahui dan menjadi mampu untuk menjelaskan karakteristik variabel yang diteliti.

\section{Populasi dan Sampel Penelitian}

Dalam penelitian ini yang menjadi populasi adalah seluruh mahasiswa perguruan tinggi swasta di Kota Padang yang jumlahnya tidak diketahui. oleh karena itu, penentuan jumlah sampel menggunakan metode Roscoe dengan sampel sebanyak 100 orang mahasiswa. Teknik pengambilan sampel menggunakan simple random sampling. 
Jurnal Manajemen dan Kewirausahaan, Volume 9, Nomor 2, Mei 2018

ISSN 2086-5031

E-ISSN 2615-3300

DOI 10.31317

\section{Teknik Pengumpulan Data}

Teknik pengumpulan data yang

HASIL PENELITIAN

DAN digunakan dalam penelitian ini adalah menggunakan kuisioner yang dibagikan kepada responden dan melakukan studi kepustakaan (library research) meliputi buku, majalah, artikel, jurnal, prosiding dan tulisan di situs internet yang berkaitan dengan masalah penelitian.

\section{Teknik Analisis Data}

Teknik analisis data yang digunakan

PEMBAHASAN

\section{Hasil Penelitian}

\section{Analisis Regresi Linear Berganda}

Hasil pengolahan data untuk mengetahui besarnya pengaruh pengetahuan kewirausahaan dan praktek kewirausahaan dalam menumbuh kembangkan perilaku kewirausahaan terlihat pada tabel berikut ini:

dalam penelitian ini adalah uji validitas, uji reliabilitas, analisis regresi linear berganda, uji t, uji F dan koefisien determinasi.

Tabel 1. Analisis Regresi Linear Berganda

\begin{tabular}{|c|c|c|c|c|c|c|}
\hline & \multirow[t]{2}{*}{ Model } & \multicolumn{2}{|c|}{ Unstandardized Coefficients } & $\begin{array}{l}\text { Standardized } \\
\text { Coefficients }\end{array}$ & \multirow[t]{2}{*}{$\mathrm{t}$} & \multirow[t]{2}{*}{ Sig. } \\
\hline & & $\mathrm{B}$ & Std. Error & Beta & & \\
\hline \multirow[t]{3}{*}{1} & (Constant) & 8.130 & 5.076 & & 2.838 & .040 \\
\hline & Pengetahuan kewirausahaan & .207 & .092 & .238 & 2.248 & .028 \\
\hline & Praktek kewirausahaan & .325 & .096 & .388 & 3.377 & .001 \\
\hline
\end{tabular}

a. Dependent Variable: perilaku kewirausahaan

Berdasarkan tabel di atas, diperoleh persamaan regresi linear berganda sebagai berikut:

$$
Y=8,130+0,207 X_{1}+0,325 X_{2}
$$

Dari persamaan di atas, dapat disimpulkan bahwa pengaruh pengetahuan kewirausahaan dan praktek kewirausahaan dalam menumbuh kembangkan perilaku 
Jurnal Manajemen dan Kewirausahaan, Volume 9, Nomor 2, Mei 2018

ISSN 2086-5031

E-ISSN 2615-3300

DOI 10.31317

kewirausahaan mahasiswa di Kota Padang adalah sebagai berikut:

1. Nilai konstanta adalah 8,130 artinya jika pengetahuan kewirausahaan dan praktik kewirausahaan tetap, maka nilai perilaku kewirausahaan mahasiswa tetap sebesar 8,130 satuan.

2. Nilai koefisien regresi pengetahuan kewirausahaan $\left(\mathrm{X}_{1}\right)$ adalah $\quad 0,207$ artinya jika pengetahuan kewirausahaan meningkat sebesar 1 satuan dengan asumsi praktek kewirausahaan $\left(\mathrm{X}_{2}\right)$ adalah nol (0), maka perilaku kewirausahaan mahasiswa di Kota Padang akan mengalami peningkatan sebesar 0,207 atau $20,7 \%$.

3. Nilai koefisien regresi praktek kewirausahaan $\left(\mathrm{X}_{2}\right)$ adalah 0,325 artinya jika praktek kewirausahaan meningkat sebesar 1 satuan dengan asumsi pengetahuan kewirausahaan $\left(\mathrm{X}_{1}\right)$ adalah nol (0), maka praktek kewirausahaan mahasiswa di Kota Padang akan mengalami peningkatan sebesar 0,325 atau $32,5 \%$.

\section{Uji t}

Hasil uji $\mathrm{t}$ dari pengolahan data penelitian adalah sebagai berikut:

1. Hasil analisis pengetahuan kewirausahaan adalah nilai sig. 0,028< 0,05 dengan nilai $t_{\text {hitung }} 2,248>t_{\text {tabel }}$ 1,984. artinya hipotesis pertama (H1) diterima yaitu terdapat pengaruh yang signifikan antara pengetahuan kewirausahaan dalam menumbuh kembangkan perilaku kewirausahaan mahasiswa.

2. Hasil analisis praktek kewirausahaan adalah nilai sig. $0,001<0,05$ dengan nilai $t_{\text {hitung }} 3,377>t_{\text {tabel }} 1,984$. artinya hipotesis kedua (H2) diterima yaitu terdapat pengaruh yang signifikan antara praktek dalam menumbuh kembangkan perilaku kewirausahaan mahasiswa.

\section{Uji F}

Hasil Uji F dijelaskan pada table berikut ini: 
Jurnal Manajemen dan Kewirausahaan, Volume 9, Nomor 2, Mei 2018

ISSN 2086-5031

E-ISSN 2615-3300

DOI 10.31317

\section{Tabel 4.2 Hasil Uji F}

\begin{tabular}{|c|c|c|c|c|c|c|}
\hline \multicolumn{7}{|c|}{ ANOVA $^{b}$} \\
\hline & & Sum of Squares & df & Mean Square & $\mathrm{F}$ & Sig. \\
\hline \multirow[t]{3}{*}{1} & Regression & 2737.369 & 3 & 912.456 & 11.988 & $.000^{\mathrm{a}}$ \\
\hline & Residual & 5328.037 & 70 & 76.115 & & \\
\hline & Total & 8065.405 & 73 & & & \\
\hline
\end{tabular}

a. Predictors: (Constant), pengetahuan kewirausahaan, praktek kewirausahaan

b. Dependent Variable: perilaku kewirausahaan

Berdasarkan tabel di atas, dapat dilihat bahwa Fhit < Ftab yaitu 11,988> 2,734 dengan tingkat signifikan $0,000<$ 0,05. Ini berarti hipotesis nol (Ho) ditolak dan hipotesis alternatif (Ha) diterima. Artinya secara bersama-sama terdapat pengaruh yang signifikan antara pengetahuan kewirausahaan dan praktek kewirausahaan dalam menumbuh kembangkan perilaku kewirausahaan mahasiswa perguruan tinggi swasta di Kota Padang.

\section{Koefisien Determinasi}

Nilai koefisien determinasi $\left(\mathrm{R}^{2}\right)$ yang diperoleh adalah sebesar 0,339 Hal ini menunjukkan bahwa sebesar $33,9 \%$ besarnya pengaruh pengetahuan kewirausahaan dan praktek kewirausahaan dalam menumbuh kembangkan perilaku kewirausahaan mahasiswa perguruan tinggi swasta di Kota Padang.

Sedangkan sisanya sebesar 66,1\% dipengaruhi oleh faktor lain yang tidak diteliti dalam penelitian ini diantaranya kepercayaan diri, jiwa kepemimpinan, dan kemampuan personal.

\section{KESIMPULAN DAN SARAN}

\section{Kesimpulan}

Kesimpulan yang diperoleh dari penelitian yang telah dilakukan dan analisis data adalah sebagai berikut:

1. Pengetahuan kewirausahaan dan praktek kewirausahaan secara parsial berpengaruh signifikan dalam menumbuh kembangkan perilaku kewirausahaan mahasiswa perguruan tinggi swasta di Kota Padang.

2. Pengetahuan kewirausahaan dan praktek kewirausahaan secara bersam-sama 
Jurnal Manajemen dan Kewirausahaan, Volume 9, Nomor 2, Mei 2018

ISSN 2086-5031

E-ISSN 2615-3300

DOI 10.31317

berpengaruh signifikan dalam menumbuh kembangkan perilaku kewirausahaan mahasiswa perguruan tinggi swasta di Kota Padang. Hal ini didukung dengan nilai Fhit < Ftab yaitu 11,988> 2,734 dengan tingkat signifikan $0,000<0,05$.

\section{Saran}

Berdasarkan hasil penelitian di atas, ada beberapa saran yang diajukan antara lain:

1. Dalam menumbuh kembangkan perilaku kewirausahaan, mahasiswa perlu meningkatkan wawasan, memanfaatkan dan berinisiatif untuk mengembangkan perilaku yang mencerminkan seorang wirausaha.

2. Bagi perguruan tinggi, perlu melakukan pembaharuan dalam memberikan dan meningkatkan pengetahuan kewirausahaan mahasiswa salah satunya dengan menggunakan metode pembelajaran yang menarik dan update, sehingga bisa diimplemementasikan oleh mahasiswa dalam bentuk perilaku.

3. Praktek kewirausahaan perlu ditingkatkan untuk mengasah pemikiran mahasiswa dalam bentuk ide-ide kreatif dan mengaplikasikannya langsung ke dalam hidup bermasyarakat. Bentuk praktek kewirausahaan yang bisa dilakukan diantaranya menciptakan suatu produk yang dibutuhkan masyarakat dengan bekerjasama dengan kampus dan masyarakat sekitar.

\section{DAFTAR PUSTAKA}

Apriliaty, Eka. (2012). Pengaruh Kepribadian Wirausaha, Pengetahuan Kewirausahaan, dan Lingkungan Terhadap Minat Berwirausaha Siswa SMK: Jurnal Pendidikan Vokasi, 2 (3). 311-324.

Azwar.S. 2012. Sikap Manusia (Teori dan Pengukurannya). Jakarta: Bumi Aksara

Kuntowicaksono. (2012). Pengaruh Pengetahuan Wirausaha dan Kemampun Memecahkan Masalah Wirausaha Terhadap Minat Berwirausaha Siswa Sekolah Menengah Kejuruan: Journal Of Economic Education, 1 (1) . 46-52.

Sekaran. U. 2006. Research Methods for Business $6^{\text {rd }}$ Edition. USA. Willey \& Sons, Inc

Sony Sumarsono. 2010. Kewirausahaan. Yogyakarta: Graha Ilmu.

Suryana. 2006. Kewirausahaan Pedoman Praktis: Kiat dan Proses Menuju Sukses, Edisi Ketiga. Jakarta: Penerbit Salemba 
Jurnal Manajemen dan Kewirausahaan, Volume 9, Nomor 2, Mei 2018

ISSN 2086-5031

E-ISSN 2615-3300

DOI 10.31317

Suryana. 2013. Kewirausahaan: Kiat dan

Proses Menuju Sukses. Jakarta: Salemba Empat

Wijaya, T. (2008). Kajian Model Empiris Perilaku Berwirausaha UKM DIY dan Jawa Tengah: Jurnal Manajemen dan Kewirausahaan, 10 (2). 93-104

Sugiyono. 2012. Metode Penelitian Kuantitatif, Kualitatif, dan $R \& D$. Bandung: CV Alfabeta

Yanti Maemunah. 2004. Pengaruh Perilaku

Kewirausahaan Terhadap Kinerja Usaha, Skripsi : UPI Bandung. 